\title{
A further investigation on the chemical constituents from Euphorbia tirucalli growing in Binh Thuan province
}

\author{
Duong Thuc Huy
}

Department of Chemistry, Ho Chi Minh City University of Education, $280 \mathrm{An}$ Duong Vuong Street, District 5, Ho Chi Minh City, Vietnam

\section{Correspondence}

Duong Thuc Huy, Department of Chemistry, Ho Chi Minh City University of Education, 280 An Duong Vuong Street, District 5, Ho Chi Minh City, Vietnam

Email: huydt@hcmue.edu.vn

\section{History}

- Received: 2019-02-26

- Accepted: 2019-05-28

- Published: 2019-06-19

DOI :

https://doi.org/10.32508/stdj.v22i2.1658

\section{Check for updates}

\section{Copyright}

(c) VNU-HCM Press. This is an openaccess article distributed under the terms of the Creative Commons Attribution 4.0 International license.

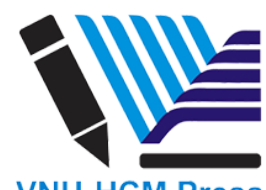

\begin{abstract}
Introduction: Euphorbia tirucalli L. is a medicinal plant popularly distributed in Asian countries. In Vietnam, only one study on the polar extract the plant Euphorbia tirucalli growing in Binh Thuan province, Vietnam was reported, revealing several phenolic components. As of 2019, no chemical reports on the non-polar extract from the Vietnamese plant were found. This research described the isolation and elucidation of compounds isolated from the non-polar extract of E. tirucalli growing in Binh Thuan province. Method: The $n$-hexane extract of this plant was carried out by using normal phase silica gel column chromatography, thin-layer chromatography, and gel chromatography (Sephadex LH-20). Analysis of spectroscopic data and Comparison of the NMR data with that in the literature led to the structural elucidation of isolated $C$ mpounds. Results: Three terpenoid compounds, euphol (1), lupenone (2), and vomifalid (3), along with ergosterol peroxide (4), ferulic acid (5), and vanillic acid (6) were isolated an elocidated. Conclusions: Among them, compound 3 and 4 were reported in the first tim for ucalli.

Key words: Euphorbia tirucalli, terpenoid, eup t, emioliol
\end{abstract}

\section{INTRODUCTION}

Euphorbia tirucalli L. is a shrub or spall ree widely distributed in Africa, Asia, and roo hing and is a medicinal plant in various tropical intries ${ }^{1}$. In India, this plant is used for ctrotreatment of cancer, asthma, and leucorrhom macological properties of E. tirucalli indic d iverse bioactivities, comprising antioxida wantimicrobial, antifungal, antiviral, anti-infla $\mathrm{nm}$ toryand cytotoxicity, as well as enzyme inh 0 y activities. Chemical profile of this plant pro ideathree common skeletons such as terpernids, molyphenols, and tannins ${ }^{1-3}$. In Vietnam, $\mathrm{ph}$ oc lemical investigation on this plant was scarce. Dur previous report focusing on the ethyl acetate extract revealed seven phenolic compounds with the ellagic acid being a major component (Le et al., 2018). As a continuation of our research focused on the diversity of bioactive metabolites from Vietnamese medicinal plants ${ }^{4,5}$, the phytochemical study was performed on the less polar extract of the title plant. Multiple chromatographic methods included normal phase silica gel column chromatography, thin-layer chromatography, and gel chromatography was applied to the $n$-hexane extract. As a result, six compounds have been obtained. Their structures were elucidated from analysis of $1 \mathrm{D}$ and 2D NMR along with a comparison with literature reports. Herein we report on the structure elucidation and isolation of six compounds.

\section{MATERIALS AND METHODS}

\section{General experimental procedures}

Bruker Advance III (500 MHz for ${ }^{1} \mathrm{H}$ NMR and 125 $\mathrm{MHz}$ for ${ }^{13} \mathrm{C}$ NMR) spectrometer with TMS as internal standard recorded NMR spectra. Chemical shifts are expressed in ppm with reference of acetone- $d_{6}$ at $\delta_{H} 2.05, \delta_{C} 206.26$ and 29.84 and of chloroform$d_{1}$ at $\delta_{H} 7.26$ and $\delta_{C} 77.80$. The HR-ESI-MS were recorded on a HR-ESI-MS Bruker microOTOF Q-II. TLC was carried out on precoated silica gel $60 \mathrm{~F}_{254}$ or silica gel 60 RP-18 $\mathrm{F}_{254} \mathrm{~S}$ (Merck Millipore, Billerica, Massachusetts, USA) and spots were visualized by spraying with $10 \% \mathrm{H}_{2} \mathrm{SO}_{4}$ solution followed by heating. Gravity column chromatography was performed with silica gel 60 (0.040-0.063 mm) (HiMedia, Mumbai, India).

\section{Plant material}

Whole plants of Euphorbia tirucalli were collected from Hong Son village, Ham Thuan Bac, in Binh Thuan province in July 2014. The botanical sample was identified by Dr. Pham Van Ngot, Department of Botany, Faculty of Biology, Ho Chi Minh University of Education. A voucher specimen (No UP002) is 

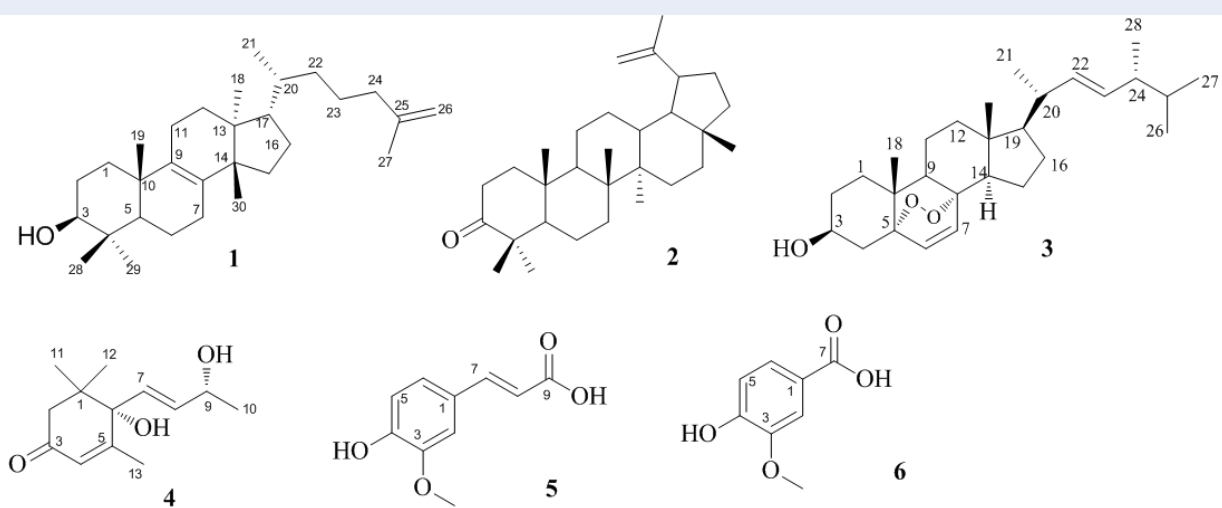<smiles>COc1cc(/C=C/C(=O)O)ccc1O</smiles><smiles>COc1cc(C(=O)O)ccc1O</smiles>

Figure 1: Chemical structures of euphol (1), lupenone (2), vomifoliol (3), ergosterol peroxide (4), ferulic acid (5), and vanilic acid (6).

deposited in the herbarium of the Department of Organic Chemistry, Faculty of Chemistry, Ho Chi Minh University of Education. to afford the actions H1-H3. Fraction H2 (15.7 g) was f cticuated by Sephadex LH-20 CC using $\mathrm{MeO}$ A to yreld three subfractions (H2.1-H2.3). Subfarion 2.1 (4.1 g) was applied to normal phase sil- ger CC and eluted isocratically with the solvent wstem $n$-hexane/EtOAc/EtOH/Acetic acid (9:2:1:0.2; $v / v / v / v)$ to give eight subfractions H2.1.1-H2.1.8. Fraction H.2.1.1 (1.8 g) was subjected to silica gel CC using $n$-hexane/EtOAc/acetone (12:1:1) to isolate compound $2(21 \mathrm{mg})$. Fraction H2.1.3 (489.0 $\mathrm{mg}$ ) was further chromatographed by reverse phase C18 silica gel CC and isocratically eluted with a $\mathrm{MeOH} /$ Acetone $/ \mathrm{H}_{2} \mathrm{O}$ (1:3:1) solvent system to obtain three subfractions H2.1.3.1-H2.1.3.3. Fraction H2.1.3.3 was rechromatographed using the solvent system $n$-hexane/chloroform/EtOAc/Acetone (100:40:24:10) to yield $\mathbf{1}(21.0 \mathrm{mg}), \mathbf{4}(3.2 \mathrm{mg}), \mathbf{5}$ $(1.8 \mathrm{mg})$, and $\mathbf{6}(4.7 \mathrm{mg})$. Fraction $\mathbf{H 2 . 3}(3.7 \mathrm{~g})$ was fractionated by normal phase silica gel CC using $n$-hexane/EtOAc/Acetone (7:1:1) as mobile phase to obtain three fractions H2.3.1-H2.3.3. Subfraction H2.3.1 (241 mg) was further purified using the same chromatographic procedure to afford $3(11 \mathrm{mg})$.

- Euphol (1). White GUM; the ${ }^{1} \mathrm{H}$ and ${ }^{13} \mathrm{C}$ NMR $\left(\mathrm{CDCl}_{3}\right)$ spectroscopic data, see Table 1.

- Lupenone (2). White amorphous powder; the ${ }^{1} \mathrm{H}$ and ${ }^{13} \mathrm{C}$ NMR $\left(\mathrm{CDCl}_{3}\right)$ spectroscopic data, see Table 1.

- Vomifoliol (3). White amorphous powder; the ${ }^{1} \mathrm{H}$ and ${ }^{13} \mathrm{C}$ NMR (Acetone- $d_{6}$ ) spectroscopic data, see Table 1.

- Ergosterol peroxide (4). Colorless needle; the ${ }^{1} \mathrm{H}$ and ${ }^{13} \mathrm{C} \mathrm{NMR}\left(\mathrm{CDCl}_{3}\right)$ spectroscopic data, see Table 2. 
- Ferulic acid (5). Colorless needle; the ${ }^{1} \mathrm{H}$ and ${ }^{13} \mathrm{C}$ NMR (Acetone- $d_{6}$ ) spectroscopic data, see Table 2.

- Vanillic acid (6). Colorless needle; the ${ }^{1} \mathrm{H}$ and ${ }^{13} \mathrm{C}$ NMR (Acetone- $d_{6}$ ) spectroscopic data, see Table 2. The NMR data are consistent with those in the literature ${ }^{6}$.

\section{RESULTS AND DISCUSSION}

Compound $\mathbf{1}$ was isolated as a white gum. The ${ }^{1} \mathrm{H}$ NMR data exhibited resonances for an isobutenyl $-\mathrm{CH}=\mathrm{C}-\left(\mathrm{CH}_{3}\right)_{2}$ group characterizing by one olefinic proton at $\delta_{H} 5.03$ and two methyls at $\delta_{H} 1.68$ and 1.61 and six upfield methyls $\left(\delta_{H} 0.76,0.80,0.86,0.88\right.$, $0.95,1.00)$, in which one was doublet $\left(\delta_{H} 0.86, \mathrm{~d}, 6.5\right.$ $\mathrm{Hz}$ ). Moreover, the ${ }^{1} \mathrm{H}$ and ${ }^{13} \mathrm{C}$ NMR spectra revealed the signal of one oxymethine at $\delta_{H} 3.25(1 \mathrm{H}$, $J=4.5,11.5 \mathrm{~Hz}$ ) and $\delta_{C} 79.1$. Analysis of the coupling pattern of this proton indicated that the hydroxy group was at $\beta$ position. The ${ }^{13} \mathrm{C}$ NMR spectrum showed the presence of 30 carbons including four sp carbons at $\delta_{C} 134.3,133.7,131.0$, and 125.4 alons with seven sp3 methylene carbons, three sp3 methi.e carbons, and five sp3 quaternary carbons. scopic features indicated the structure to 19 tetracyclic tritepenes such as euphanes or tiructans (Ghosh, 2017). The comparison of NMR ta 1 y ith those of euphol ${ }^{7}$ showed that they rere ide, rical, thus 1 was elucidated as euphol.

Compound 2 was isolat an amoun powder. The ${ }^{1}$ H NMR o a hil ited seven singlet methyls $\left(\delta_{H} 0.80,0.93,96\right.$, $1.03,1.07,1.07$, and 1.68), two gem olefinic an $\delta_{H} 4.57$ and 4.69 with the coupling on a being $J=2.5 \mathrm{~Hz}$. The ${ }^{13} \mathrm{C}$ NMR spect howed the presence of 30 carbons includin 0 e 2 substituted carbon at $\delta_{C} 151.1$ and one sp mylene at $\delta_{C} 109.9$ which was assignable for isopropenyl group $-\mathrm{C}\left(\mathrm{CH}_{3}\right)=\mathrm{CH}_{2}$, one ketone carbon at $\delta_{C} 218.5$, ten methylene carbons, five methine carbons, and five quaternary carbons. The comparison of NMR data of 2 with those of lupenone ${ }^{8}$ showed that they were identical; thus 2 was elucidated as lupenone.

Compound 3 was isolated as a white amorphous powder. The ${ }^{1} \mathrm{H}$ NMR spectrum exhibited signals for six methyl groups at $\delta_{H} 0.81(\mathrm{~s}, \mathrm{H}-19), 0.83(\mathrm{~d}, \mathrm{~J}=6.5$ $\mathrm{Hz}, \mathrm{H}-27), 0.82$ (d, J = 7.0 Hz, H-26), 0.88 (s, H18), $0.91(\mathrm{~d}, \mathrm{~J}=7.0 \mathrm{~Hz}, \mathrm{H}-28)$ and $1.00(\mathrm{~d}, \mathrm{~J}=6.5$ $\mathrm{Hz}, \mathrm{H}-21$ ), four olefinic protons containing two signals at $\delta_{H} 5.14(\mathrm{dd}, \mathrm{J}=15.5,7.7 \mathrm{~Hz}, \mathrm{H}-22)$ and 5.22 (dd, J $=15.5,7.7 \mathrm{~Hz}, \mathrm{H}-23$ ) assignable for the double bond C-22-C-23 and two signals at $\delta_{H} 6.24(\mathrm{~d}, \mathrm{~J}=$
$8.5 \mathrm{~Hz}, \mathrm{H}-6)$ and $6.50(\mathrm{~d}, \mathrm{~J}=8.5 \mathrm{~Hz}, \mathrm{H}-7)$ assignable for the double bond at C-6-C-7, one oxymethine at $\delta_{H} 3.97(\mathrm{~m}, \mathrm{H}-3)$ and twenty protons at $\delta_{H} 1.23-$ 2.10. The ${ }^{13} \mathrm{C}$ NMR spectrum showed the presence of 28 carbons, including six methyls, seven methylenes, eleven methines (one bearing oxygen and four olefinic carbons) and four quaternary carbons (two bearing oxygen). The NMR data of $\mathbf{3}$ were similar to those of $(5 \alpha, 8 \alpha)$-ergosterol peroxide ${ }^{9}$; thus it was assigned being $(5 \alpha, 8 \alpha)$-ergosterol peroxide.

Compound 4 was obtained as a white amorphous powder. The ${ }^{1} \mathrm{H}$ NMR spectrum exhibited one trans double bond $\left(\delta_{H} 5.88\right.$, dd, 15.5, 4.5 and 5.84, d, 15.5, $10.5)$, one olefinic proton $\left(\delta_{H} 5.85, \mathrm{br}\right)$, four methyls $\left(\delta_{H} 1.00,1.04,1.20,1.88\right)$, one oxymethine $\left(\delta_{H} 4.33\right.$, $\mathrm{m})$, one methylene $\left(\delta_{H} 2.42\right.$, d, 16.5 and $\left.2.10, \mathrm{~d}, 16.5\right)$. The ${ }^{13} \mathrm{C}$ NMR spectrum showed signals of 13 carbons includis one ketone carbon, four olefinic carbons, fou netbls, one oxymethine, one methylene and tornary carbons, one of which was oxygena d (able 2). HMBC cross peaks of H-7, H-8, H 3 , $\mathrm{H}_{3}-12, \mathrm{H}_{3}-13$ to $\mathrm{C}-6$ defined the attachment ot he hydroxy group at this carbon while $\mathrm{HMBC}$ correlations of $\mathrm{H}_{3}-11$ to $\mathrm{C}-2$, of $\mathrm{H}_{2}-2$ to $\mathrm{C}-3$ and $\mathrm{C}-4$, of H-4 to C-2 and C-3, of $\mathrm{H}_{3}-13$ to $\mathrm{C}-4$ and C-5 defined the connectivity through C-1-C-6 (see Figure 3). Besides, $\mathrm{H}-9$ gave $\mathrm{HMBC}$ cross peaks to $\mathrm{C}-9$ and $\mathrm{C}-10$ and vice versa $\mathrm{H}_{3}-10$ gave $\mathrm{HMBC}$ correlations to $\mathrm{C}-8$ and C-9, indicating the structure of the side chain (see Figure 3). The comparison of NMR data of 4 with those of vomifoliol ${ }^{10}$ showed that they were identical, thus 4 was elucidated as vomifoliol.

Compound 5 was obtained as a white amorphous powder. The ${ }^{1} \mathrm{H}$ NMR spectrum of 5 revealed the presence of an $\mathrm{ABX}$ benzenoid system, a $(E)$ configured double bonds $\left(\delta_{H} 7.31 \mathrm{~d}, 15.5\right.$ and 6.97, d, $15.5)$, one hydroxy group $\left(\delta_{H} 7.95\right)$, and one methoxy group $\left(\delta_{H} 3.91\right)$. The ${ }^{13} \mathrm{C}$ NMR spectrum of $\mathbf{5}$ showed signals of one carbonyl carbon $\left(\delta_{C} 168.1\right)$, three aromatic methines, two olefinic carbons, and three substituted aromatic carbons, two of which were oxygenated $\left(\delta_{C} 146.3\right.$ and 148.6). HMBC correlations of both $\mathrm{H}-7$ and $\mathrm{H}-8$ to $\mathrm{C}-1$ and $\mathrm{C}-9$ defined the connectivity of the side chain to C-1 of the benzene ring. In addition, $\mathrm{HMBC}$ cross peaks of all $\mathrm{H}-$ $2, \mathrm{H}-5$, and $\mathrm{OCH}_{3}$ to $\mathrm{C}-3$ defined the position of the methoxy group while $\mathrm{HMBC}$ cross peaks of all $\mathrm{H}-2$, $\mathrm{H}-6$, and 5-OH to C-4 defined the attachment of a hydroxy group at C-4. NMR data of $\mathbf{5}$ closely resembled those of ferulic acid ${ }^{3}$; accordingly, 5 was elucidated as ferulic acid.

Euphol (1), a common component from Euphorbia tirucalli growing in the world had strong cytotoxicity toward various cancer cell lines, anti-inflammatory 
Table 1: Nuclear magnetic resonance of compounds 1-3 (in $\mathrm{CDCl}_{3}$ )

\begin{tabular}{|c|c|c|c|c|c|c|}
\hline \multirow[t]{2}{*}{$\mathrm{N}$} & \multicolumn{2}{|c|}{$1^{a}$} & \multicolumn{2}{|c|}{$2^{b}$} & & \multirow[t]{2}{*}{3} \\
\hline & $\delta_{H}, J(\mathrm{~Hz})$ & $\delta_{C}$ & $\delta_{H}, J(\mathrm{~Hz})$ & $\delta_{C}$ & & \\
\hline 1 & & 35.6 & & 39.8 & & 34.9 \\
\hline 2 & & 28.1 & $\begin{array}{c}2.40, \mathrm{~m} ; 2.49 \\
\mathrm{~m}\end{array}$ & 34.3 & & 30.2 \\
\hline 3 & $\begin{array}{c}3.20 \text {, dd, } 4.5, \\
11.5\end{array}$ & 79.3 & & 218.5 & 3.97, m & 66.5 \\
\hline 4 & & 37.4 & & 47.5 & & 37.1 \\
\hline 5 & & 50.1 & & 55.1 & & 82.3 \\
\hline 6 & & 19.1 & & 19.8 & & 135.6 \\
\hline 7 & & 27.8 & & 33.7 & & 130.9 \\
\hline 8 & & 134.3 & & & & 79.6 \\
\hline 9 & & 133.7 & & & & 51.3 \\
\hline 10 & & 39.1 & & & & 37.1 \\
\hline 11 & & 21.7 & & 21.1 & & 23.6 \\
\hline 12 & & 28.2 & & 25.3 & & 39.3 \\
\hline 13 & & 44.3 & & 38.4 & & 44.6 \\
\hline 14 & & 50.2 & & 43.2 & & 51.7 \\
\hline 15 & & & & 27.6 & & 20.6 \\
\hline 16 & & & & 36.0 & & 28.9 \\
\hline 17 & & 9.8 & & 43.1 & & 56.2 \\
\hline 18 & & 15.8 & & 48.4 & $0.88, \mathrm{~s}$ & 18.3 \\
\hline 19 & & 20.3 & 2.37, m & 48.1 & $0.81, \mathrm{~s}$ & 13.0 \\
\hline 20 & & 36.0 & & 151.1 & & 39.9 \\
\hline & $0.86, d, 6.5$ & 19.1 & & 30.1 & $1.00, \mathrm{~d}, 6.5$ & 21.0 \\
\hline & & 35.4 & & 40.1 & $5.14, \mathrm{dd}, 15.5,7.7$ & 135.4 \\
\hline 3 & & 24.9 & $1.07, \mathrm{~s}$ & 26.6 & $5.22, \mathrm{dd}, 15.5,7.7$ & 132.5 \\
\hline 24 & $5.03, t, 7.0$ & 125.4 & $1.03, \mathrm{~s}$ & 21.2 & & 42.9 \\
\hline 25 & & 131.0 & $0.93, \mathrm{~s}$ & 16.1 & & 33.2 \\
\hline 26 & $1.68, \mathrm{~s}$ & 25.9 & $1.07, \mathrm{~s}$ & 16.0 & $0.82, d, 7.0$ & 19.8 \\
\hline 27 & $1.61, \mathrm{~s}$ & 17.8 & $0.96, \mathrm{~s}$ & 14.6 & $0.83, \mathrm{~d}, 7.0$ & 20.1 \\
\hline 28 & $0.88, \mathrm{~s}$ & 24.6 & $0.80, \mathrm{~s}$ & 18.2 & $0.91, \mathrm{~d}, 6.5$ & 17.7 \\
\hline 29 & $1.00, \mathrm{~s}$ & 28.3 & $\begin{array}{c}4.69, \mathrm{~d}, 2.5 \\
4.57, \mathrm{dd}, 2.5 \\
1.5\end{array}$ & 109.9 & & \\
\hline 30 & $0.76, \mathrm{~s}$ & 15.7 & $1.68, \mathrm{~s}$ & 19.5 & & \\
\hline
\end{tabular}


Table 2: Nuclear magnetic resonance of compounds 4-6 (in acetone- $d_{6}$ )

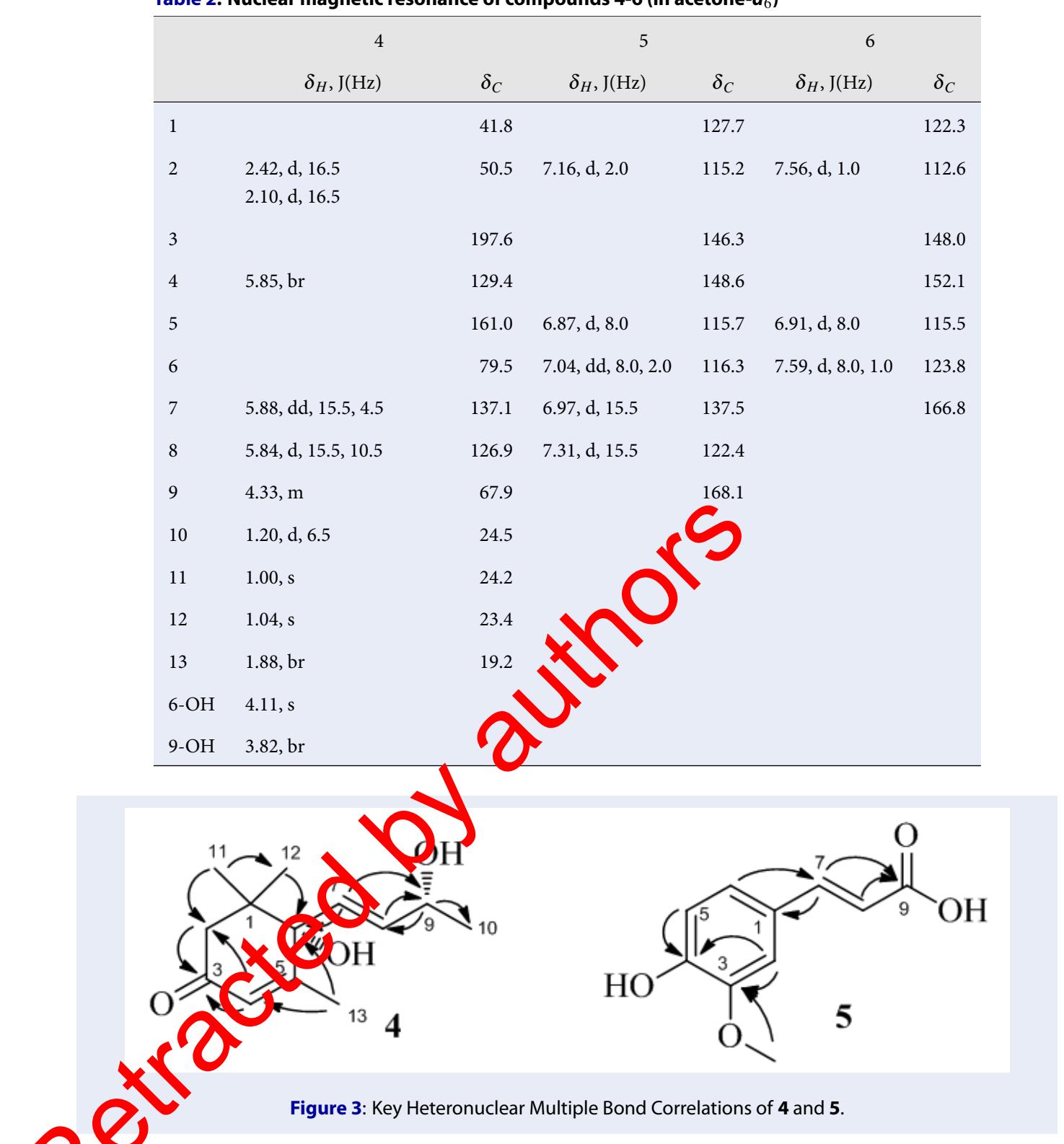

activity as well as diverse pharmacological properties ${ }^{1,11-13}$. Lupenone (2) was found in the first time from the plant E. tirucalli growing in China ${ }^{14}$ since 2011 but it could be found in many higher plants belonging to the Euphorbia genus. Ferulic acid (5) was reported as a significant phenolic compound detected through HPLC-UV in all extracts of E. tirucalli from Brazil $^{3}$ and proposed to be responsible to the high antioxidant of this plant; nevertheless, this compound was isolated with the minute amount. Although compound 3 and $\mathbf{4}$ have been investigated from some Euphorbia plants, such as vomifoliol from E. heteradena $^{15}$, Euphorbia prostrate ${ }^{16} \ldots$ or ergosterol per- oxide from $E$. lagascae ${ }^{17,18}$, to the best of our knowledge, two compounds $\mathbf{3}$ and $\mathbf{4}$ were isolated from this species for the first time.

\section{CONCLUSION}

From the plant E.tirucalli growing in Binh Thuan province, six compounds were isolated and elucidated as being euphol (1), lupenone (2), vomifoliol (3), ergosterol peroxide (4), ferulic acid (5), and vanillic acid (6). Two compounds 3 and $\mathbf{4}$ were isolated from this species for the first time. 


\section{ABBREVIATIONS}

${ }^{1} \mathrm{H}$ NMR: Proton nuclear magnetic resonance, ${ }^{13} \mathrm{C}$ NMR: Carbon-13 nuclear magnetic resonance, CC: column chromatography, TLC: Thin layer chromatography, HSQC: Heteronuclear single quantum coherence, HMBC: Heteronuclear multiple bond correlation, s: singlet, d: doublet, m: multiplet

\section{CONFLICTS OF INTEREST}

The authors declare no competing financial interest.

\section{AUTHOR CONTRIBUTION}

Duong T. H. has contributed in conducting experiments, acquisition of data, interpretation of data, searching the bibliography and gave final approval of the manuscript to be submitted.

\section{ACKNOWLEDGMENTS}

We would like to thank Dr. Pham Van Ngot for the identification of the scientific name.

\section{REFERENCES}

1. Mwine TJ, Van Damme P. Euphorbia tiruca L.(Euphorbiaceae): the miracle tree: current status available knowledge. Scientific Research and Ess, vs. 2011;6:4905-4914.

2. Avelar BA, Lélis FJN, Avelar RS, Weber M, Souza-Fa gur des EM, Lopes MTP, et al. The crude latex of uphorbla tirucalli modulates the cytokine response or buk cytes, especially CD4+ T lymphocytes. Revis $P$ as, vira a Farmacognosia. 2011;21:662-667. Available 1, tm: ttps./doi.org/10. 1590/S0102-695X20110050000

3. de Araújo K, de Lima A, Si va Rodrigues L, Amorim A Quelemes $\mathrm{P}$, et al. Identificat $\mathrm{n}$ of Menolic Compounds and Evaluation of Antioxida it a,d Antimicrobial Properties of Euphorbia Tirucalli L. Ant, xid hts. 2014;3:159-175. Available from: https://doj on/ 3290/antiox3010159.

4. Duong TH, Ben ddir MA, Nguyen VK, Aree T, Gallard JF, Mac $\mathrm{DH}$, et al Acid-Containing Flavonoids from the Roots of $\mathrm{Pl}$ la whus acidus. Journal of Natural Products. 2018; 202 2031. Available from: https://doi.org/10.1021/ acs., atp d. 8 b00322.

5 D. ong $\rightarrow H$, Bui XH, Pogam PL, Nguyen HH, Tran TT, Chavasiri $\checkmark v$ al. Two novel diterpenes from the roots of Phyllanthus acidus (L.) Skeel. Tetrahedron. 2017;73:5634-5638.

6. Chang SW, Kim KH, Lee IK, Choi SU, Ryu SY, Lee KR. Phytochemical Constituents of Bistorta manshuriensis. Natural Product Sciences. 2009;15:7.
7. Zhang L, Gao L, Li Z, Yan X, Yang Y, Tang Y, et al. Bio-Guided Isolation of the Cytotoxic Terpenoids from the Roots of Euphorbia kansui against Human Normal Cell Lines L-O2 and GES-1. Int J Mol Sci. 2012;13:11247-11259. Available from: https://doi.org/10.3390/ijms130911247.

8. Cota BB, Siqueira EP, de Oliveira DM, Alves TMA, Sobral MEG, Rabello $A$, et al. Chemical constituents and leishmanicidal ac tivity from leaves of Kielmeyera variabilis. Revista Brasileira de Farmacognosia. 2012;22:1253-1258. Available from: https: //doi.org/10.1590/S0102-695X2012005000095.

9. Souza EMC, de Silva ELD, Marinho AMR, Marinho PSB, Souza EMC, de Silva ELD, et al. (4S)-4,8-dihydroxy-1-tetralone and other chemical constituents from Pestalotiopsis sp. EJC07, endophytic fromBauhinia guianensis. Anais da Academia Brasileira de Ciências. 2016;88:29-33. Available from: https: //doi.org/10.1590/0001-3765201620140378.

10. Hammami S, Jannet HB, Bergaoui A, Ciavatta L, Cimino G, Mighri Z. Isolation and Structure Elucidation of a Flavanone, a Flavanone Glycoside and Vomifoliol from Echiochilon Fruticosum Growing in Tunisia. Molecules. 2004;9:602-608. Available from: https://doi.org/10.3390/90700602.

11. Chen CL, Chen YP, Lin MW, Huang YB, Chang FR, Duh TH, et al. Euphol from Euphorbia tirucalli Negatively Modulates TGF- $\beta$ Responsiy -nesc via TGF- $\beta$ Receptor Segregation inside Membrane afts. PD S ONE. 2015;10:e0140249. Available from: https:/ i.org/10.1371/journal.pone.0140249.

12. $\mathrm{L}$, win AS, Wu DC, Wang SSW, Chang FR, Wu YC, el. Euphol from Euphorbia tirucalli selectively inhibits man gastric cancer cell growth through the induction of ERK1/2-mediated apoptosis. Food and Chemical Toxicology. 2012;50:4333-4339. Available from: https://doi.org/10.1016/j. fct.2012.05.029.

13. Silva VAO, Rosa MN, Tansini A, Oliveira RJS, Martinho O, Lima $J P$, et al. In vitro screening of cytotoxic activity of euphol from Euphorbia tirucalli on a large panel of human cancer-derived cell lines. Exp Ther Med. 2018;16:557-566. Available from: https://doi.org/10.3892/etm.2018.6244.

14. Wang $X Y$, Liu LP, Kang TG, Wang HB. Chemical constituents from Euphorbia tirucalli; 2011.

15. Öksüz S, Ulubelen A, Barla A. Terpenoids and Aromatic Compounds from Euphorbia heteradena. Turkish Journal of Chemistry. 2002;26:457-464.

16. Voukeng IK, Beng VP, Kuete V. Multidrug resistant bacteria are sensitive to Euphorbia prostrata and six others Cameroonian medicinal plants extracts. BMC Res Notes. 2017;10:10-1186. Available from: https://doi.org/10.1186/s13104-017-2665-y.

17. Duarte N, Ferreira MJU, Martins M, Viveiros M, Amaral L. Antibacterial activity of ergosterol peroxide against Mycobacterium tuberculosis: dependence upon system and medium employed. Phytotherapy Research. 2007;21:601-604. Available from: https://doi.org/10.1002/ptr.2119.

18. Tan W, Pan M, Liu H, Tian H, Ye Q, Liu H. Ergosterol peroxide inhibits ovarian cancer cell growth through multiple pathways. Onco Targets Ther. 2017;10:3467-3474. Available from: https://doi.org/10.2147/OTT.S139009. 